\title{
Innovation of Apperception's activity in French Language Learning for Beginners through Activité Ludique
}

\author{
Sri Handayani ${ }^{1}$, Suluh Edhi Wibowo ${ }^{2}$ \\ \{ srihandayani@mail.unnes.ac.id ${ }^{1}$, suluhedhiwibowo94@gmail.com² $\}$ \\ Universitas Negeri Semarang, Indonesia ${ }^{1,2}$
}

\begin{abstract}
Activité ludique is a fun activity applied in language learning that enables having interactive and cooperative activity. This activity can be done at every learning step. One of them is apperception, held at the beginning of learning process and aims to draw the attention of learners. As a part of learning process, apperception takes an important role to determine the success of learning. However, many teachers consider that apperception is negligible. In this regard, this study was held which aims to propose activité ludique as a variation of the apperception for beginner level French learning. The method used is research and development method for creating an innovation learning model. The result is a model of apperception activities for beginner level French learning based on activité ludique. This model can be applied in learning French both in high school and in college in order to create learning process more innovative and fun.
\end{abstract}

Keywords: Apperception, Activité Ludique, Innovation, Language Teaching, Learning Process

\section{Introduction}

Each learning process consists of several steps. In general, there are three core activities in learning, namely opening activities, main activities, and closing activities. One component in planning the learning process is a preliminary activity carried out to prepare learners who are directly related to the material to be discussed. Besides, the initial activities carried out to arouse the motivation and attention of learners in participating in learning, explain the activities to be passed, and show the relationship between children's experiences with the material to be learned.

In connection with the initial activities to open lessons, teachers are expected to have competence in implementing apperception. Because apperception activities also determine the success of learning and the achievement of learning objectives that have been set. The function of the initial learning activities is to create an effective learning start so that the learner is fully prepared to follow the core learning activities. These activities can be used by teachers to improve the concentration and motivation of learners starting from the beginning of learning until the lesson ends. The duration of apperception activities generally ranges from 5-15 minutes.

Apperception is connecting old lessons with new lessons, which can be in the form of stories, songs, videos or pictures [1]. The term apperception in French can be likened to accroche, which is an activity that aims to attract attention. This accroche usually appears among others in advertisements, newspapers, magazines, and does not rule out the possibility 
in the learning process because it is to attract attention. In the world of teaching, accroche is done at the beginning of learning to attract learners' attention to the material to be taught.

An example of accroche or apperception in learning French is the guessing game of the country's flag. This activity is in accordance with material presenter or introduction. Learners are asked to guess the name of the country based on the flag displayed on the PPT. Through this activity, students are transferred to enter citizenship material. This activity is also expected to lead to motivation in learners to follow the learning process.

But not all teachers do apperception learning. A preliminary study in the form of observations was conducted on French language teachers in Semarang during the Field Experience Practice. From the results of observations note that the teacher did not over emphasize the implementation of apperception at the beginning of learning. There are teachers who leave apperception and go directly to the main activity. There are teachers who do apperception but are limited to question-and-answer activities. When examined, there are mandatory sentences that are often spoken by teachers when starting lessons, namely:

"What did we learn at the last meeting?"

"Does anyone still remember last week's lesson?"

These sentences tend to become standard patterns and sound boring if asked repeatedly. This can affect the ability of learners during the learning process. They tend to be less ready to learn, both physically and psychologically.

There are several ways teachers can use in giving apperception, including fun stories, ice breaking, music, brain gym and games. In this regard, in teaching French there are activities that are usually done to make the learning atmosphere more interesting, namely activité ludique which can be interpreted as a fun activity. A learning activity is called ludique when it's guided by rules of play and practiced for the pleasure it provides. It allows a communication between learners. This activity is carried out so that learning activities become more fun without forgetting the principal goal of learning. At a glance, activité ludique is likened to a game [2].

Examples of this activity include jeu sensoriel, a game of touching and guessing objects in a bag and describing the object. Generally, there are 4 types of this activity [2]:

a. Language games, which include grammatical, morphological, lexical, phonetic and orthographic levels. This activity requires more thought from the learner.

b. Creativity games, which allows learners to develop their imagination. Examples of this activity are guessing words, charades, anagrams, lipograms.

c. Culture games, which focus on learner cultural knowledge, such as geographical and culinary knowledge of the French country.

d. Role-play, carried out by conditioning the classroom as if it were a theater performance, the learner is an actor.

A study on Character Apperception for French Language Learning in High School has been conducted in 2014. This research focuses on internalizing character values in learning process; one of them is through apperception activities. The results of this study are a collection of apperception activities to start learning that includes character values for examples of character apperception activities that can be practiced in language classes by integrating character values in these activities. Character values are included in one of the learning activities as an affective domain representation in learning [3].

Some of the results of previous studies serve as references and references in the conduct of this study corresponding to activité ludique and apperception. The first study was $L a$ créativité associée au jeu en classe de Français Langue Étrangère. Silva discusses the 
problematic understanding of creativity and games, comparison of game creativity in the 70's with todays. After identifying the game in a language class, it was finally concluded that an appropriate way was needed to further exploit the creative game in the FLE class. In addition, there are problems relating to games in language classes, including: 1) the formation of operational definitions, 2) reflection on the epistemological status of creativity and games, 3) transversality, 4) game creativity [4].

The next article that is referred to is Introduire l'activité Brise-glace aux professeur du lycée à Semarang in 2015. The aim of the research is to solve the problems faced by high school teachers in learning French, when they face student boredom. Ice breaking activity is the right solution given to overcome student boredom. Therefore, examples of ice breaking are compiled that are suitable for learning French in high school [5].

Pour l'utilisation de l'activité ludique en Algérie dans la classe de FLE is an article discussing the experiments carried out in elementary school which focused on classroom observations with the aim of identifying activité ludique to support learning. The results showed through ordinary activities, $30 \%$ of students were able to understand the material, and through activité ludique, students who understood more material, namely $80 \%$. So, it can be concluded that activité ludique is useful and effective in explaining material [6].

The next study discussed the Application of variations in apperception and interactive learning activities to increase learning activities and the ability of students' pronunciation in Pronunciation Practice Courses. This study aims to find out the appropriate learning methods to be used in the process of learning the Pronunciation Practice course. It was found that interactive learning strategies with inquiry methods and group discussions were the most appropriate strategies and methods used in the Pronunciation Practice course where students had more opportunities to explore individual abilities as a group. In addition, an increase in apperception activities at the beginning of learning enables students to build awareness and self-readiness on learning material [7].

Previous research shows that apperception and activité ludique are not new in language learning. Therefore, to complete the existing research, this research discusses the development of activité ludique as a variation of apperception activities for French's beginner learners.

Based on the description above, there are 2 problems discussed in this study:

a. How is the development of activité ludique that can be used for apperception in learning

French at the beginner level?

b. How is the final product produced?

c. What is the result of product's application in classroom?

\section{Research Method}

This research is a development research using the $\mathrm{RnD}$ approach to develop a new product in the form of apperception activities for learning French. The target in this study is the development of apperception variations for beginner level French language learning that has been adapted to French language material in high schools and universities.

The development research steps refer to the development research design according to Sukmadinata [8], which modify Gall and Borg's theories, namely: 1) Preliminary studies which include literature studies, field surveys, and preparation of draft models. Review of the draft by experts, and its refined based on expert's suggestion; 2) The test of model which carries out in two steps: limited and extensive testing; 3 ) final test of product and its socialization. 


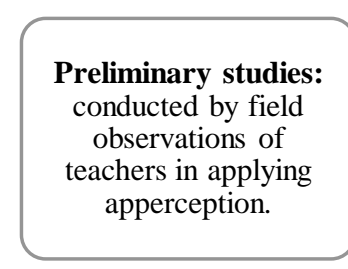

Revision of the draft: according to suggestions so as to produce a collection of activité ludique as variation in apperception.
Need analysis: to determine the needs of the audience for the product to be developed through questionnaires for French's highscholl teacher and lecturer.
Literature: to gather theories and materials to compile French apperception activities, including games, stories and audio-visual documents.

Preparation of draft models the design of activité ludique as a variation of apperception activities for the beginner.
Test of model: conducted at the French Language Education Program for limited trial, while extensive trials were carried out at both of university and in high schools.
Review of the draft: to provide suggestion on the draft of the French apperception activity and to assess for knowing its weaknes and strength.

Fig. 1. Illustrates the research steps.

Before creating the product, there are two techniques used for collecting the data: observation and questionnaires. Observation is used to get data about apperception activities in French learning process. Meanwhile, to obtain information about the type of apperception that teachers want, the questionnaire technique was applied. The following are the observation and questionnaire grids:

Table 1. Observation grid

\begin{tabular}{clc}
\hline No. & \multicolumn{1}{c}{ Indicators } & Used Unused \\
\hline 1 & Realization of apperception in class & 1 \\
2 & Ways to give apperception & 1 \\
3 & Realization of activité ludique in class & 1 \\
4 & Type of activité ludique used & 1 \\
\hline
\end{tabular}

Table 1 is the observation grid for obtaining the initial information about the implementation of apperception in class.

Table 2. Questionnaire grid

\begin{tabular}{clc}
\hline No. & \multicolumn{1}{c}{ Indicators } & Number of items \\
\hline 1 & Use of apperception in class & 1 \\
2 & Type of apperception applied & 1 \\
3 & Needs of variation of apperception & 1 \\
\hline
\end{tabular}




\begin{tabular}{lll}
\hline 4 & Expected type of apperception & 1 \\
5 & Expected form of product & 1 \\
\hline
\end{tabular}

Table 2 contains the questionnaire grid to reveal the needs of the research's product, covering the use and the type of apperception used and expected to have in the product.

\section{Findings and Discussion}

There are three problematics proposed at the introduction that will be answered in this section. First part is finding which discusses the product design steps including preliminary study, needs analysis and product design. Second part is the discussion, showing the final product and revealing the application of product in classroom.

\subsection{Findings}

This research begins with a finding of preliminary study to see the circumstances and phenomena in field in the form of observation and informal interviews with several high school's French language teachers and university's lecturers. Based on observations and interviews with 3 French teachers and 10 teachers in Semarang and it surrounding areas, the following results are obtained:

a. $40 \%$ of respondents do not do apperception learning activities. They begin learning process with greetings and immediately ask students to open the lesson.

b. $60 \%$ of respondents give apperception by inviting students to ask questions about the material that has been taught. For example: "What's the French word of family? Father? Younger brother?". By doing this activity, only one or two students will answer it. The other students just quietly waited for their turn to be appointed to answer.

c. Respondents take students to learn new material simply by saying "Today we will study the $X$ material”, especially for learning in universities, because the public is bigger and more mature, then apperception does not get much attention.

d. Teachers have implemented activité ludique as a distraction, to bring learning process to be more enjoyable.

After observing and interviewing, a needs analysis is also done by distributing questionnaires. This activity aims to determine the needs of the public about the existence of apperception activities based on activité ludique. The results of the needs analysis show that:

a. The type of apperception that was used was ice breaking, music and games. Language games are often initiated in class.

b. The type of apperception that teachers and learners want is fun stories, ice breaking, music, brain gym, language games, culture games and creativity games.

c. The expected final form of the product is a book on apperception based on activité ludique.

The result of needs analysis is used as a reference and consideration for developing a product which is, an apperception book for beginner-level French language learning based on activité ludique. The material in the book refers to French learning material in high school and first year at the university level, as a beginner level French learning material. The table 3 shows the activities for each content. 
Table 3. Product Design

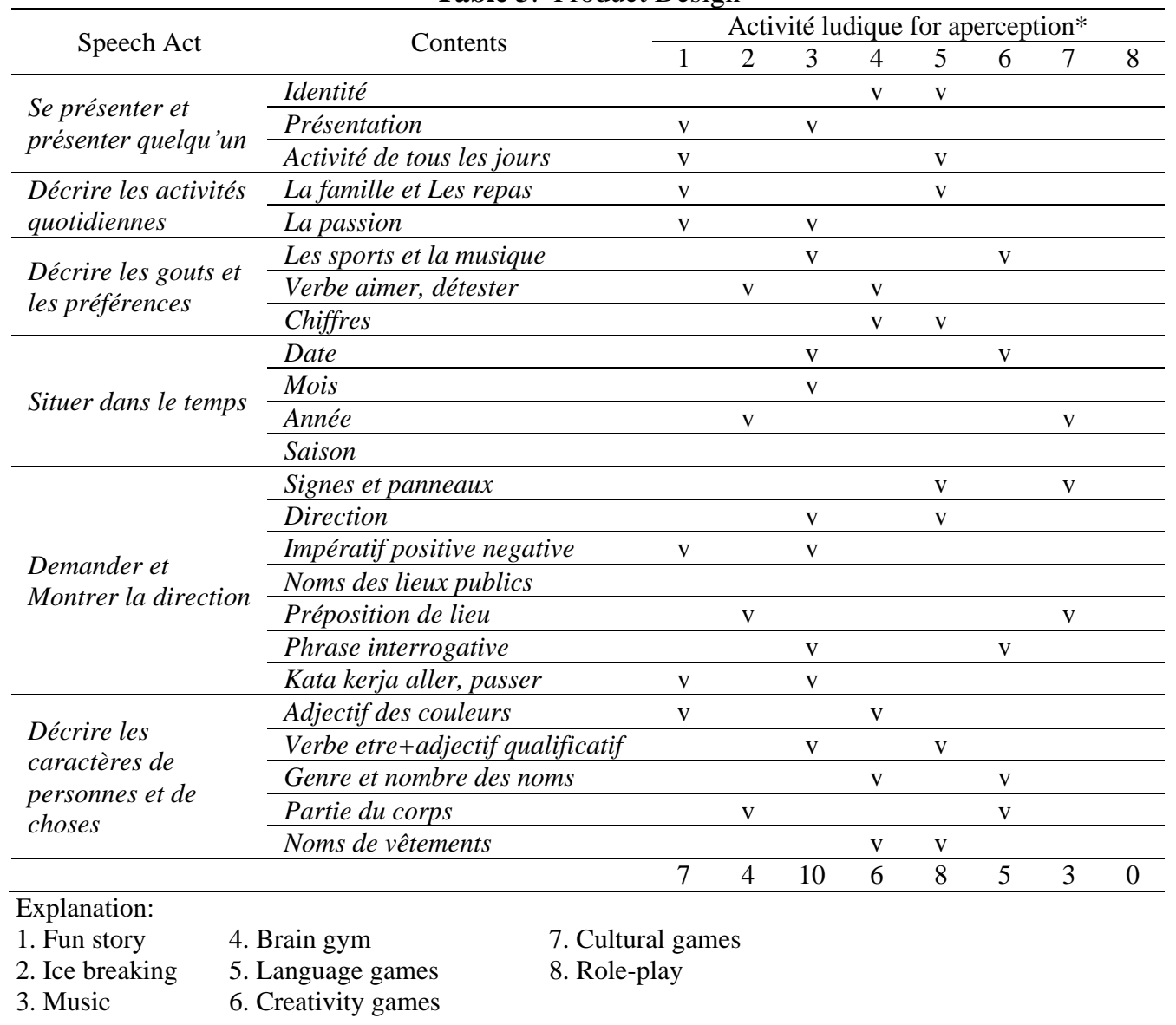

The design grid showed in table 3 is used as a reference to compile apperception activity based on activité ludique in form of a book.

\subsection{Discussion}

This discussion part contains the description of product, suggestion for the product and its trial in class.

\subsubsection{Creation of Product}

The product contains seven sections, which are front page or cover page, preface page, table of contents, contents, bibliography, author's identity and back page. The product can be seen in the discussion of product parts as follows:

a. Front page or Cover

The first arrangement of this product is the book cover. On this cover there is a purple background with gradations of pink, purple and yellow. Purple reflects the power of creativity and imagination while the color pink reflects compassion, with the hope that the teacher is able 
to teach students by heart. There are three main figures on the cover: dice, musical note and a group of people, describing various activities can be done in apperception including music, games and ice breaking. Also, figure of a group of people depicting teachers and learners who are doing activité ludique in the classroom. Book's cover can be seen on figure 2.

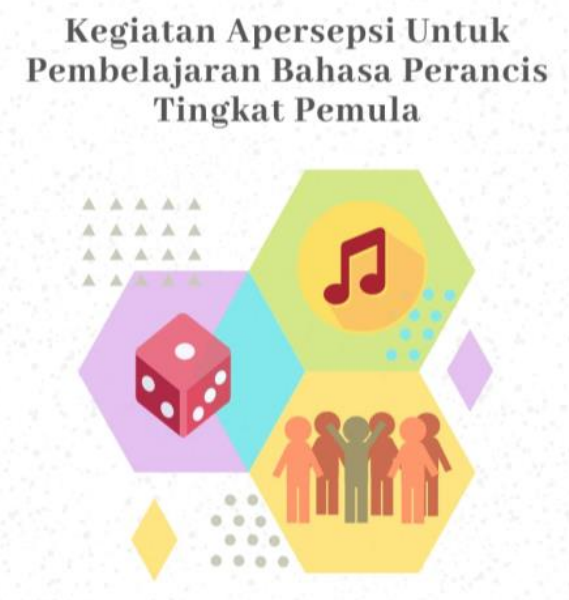

Fig. 2. Book's Cover.

b. Foreword page

On this page there is a preface written by the author. In the foreword it is mentioned the background of making the product, thanks to related parties, and closing.

c. Table of contents

In this section there is a table of contents and pages of book products. The purpose of the table of contents is to make it easier for readers to find the desired page.

d. Contents

The Contents section contains the core of this product, which is various activité ludique carried out for apperception of French learning. Each activity contains the title of the activity, material, learning objectives, apperception goals, tools and materials, the stage of implementation and visualization of images. The following are examples of each type of activity:

1) Title: Follow What I Say!

Type: Fun Story

Contents: jours de la semaine (Days of the week)

Learning objectives: Being able to mention the names of days in French

The purpose of the activity: delivering material for days of the week

Tools and materials: -

Implementation:

This variation is one of the fun story activities in the form of puzzles. In this activity students must have a high concentration and understand the commands of the teacher. This puzzle is done to develop students' knowledge about the names of the days (les jours) in French. The teacher gives instructions for the students' activities, the 
instructions are 'follow what I say!' And students must say whatever the teacher says. This activity trains students to always follow the teacher's instructions correctly. The purpose of this activity for students is to be able to mention name of days in French with the correct pronunciation.

2) Title: Mes ballons

Type: Music

Content: couleurs (colors)

Learning objectives: Being able to mention the color of objects in French

The purpose of the activity: repeat the color subject

Tools and materials: -

Implementation:

This variation is used to develop students' knowledge about colors through a song. The type of apperception used in this activity is music. In this activity, the teacher will play a song called Mes ballons which is a French translation of the children's song Balonku. This song contains several colors in French. After the teacher plays the song, students sing together with the teacher the song. The purpose of this activity is to name colors in French with the correct pronunciation. The following is the lyric of the song Mes Ballons:

J'ai cinq ballons dans ma main, mes ballons sont colorés

Le vert, le jaune, et le gris, le rose et aussi le bleu

Le ballon vert est éclaté, bang! Ça fait mon cœur effrayé

Et je n'ai qu'un seul ballon, je le tiens étroitement.

3) Title: Funny Finger

Type: Brain gym

Content: chiffres (number)

Learning objectives: Being able to mention numbers in French

The purpose of the activity: repeat numbers

Tools and Materials: fingers

Implementation:

- The teacher mentions numbers in Indonesian or French and gives examples of the position of numbers with a finger display: number one is displayed by showing the thumb. Number two is displayed with the position of the fingers ready to shoot. Number three is indicated with the position of a metal finger. Number four is presented by the position of the thumb bent and number five is represented by the position of hi-five.

- Teacher mentions numbers one by one randomly and asks students to demonstrate the position of the finger's number.

- As variation, to mentioning the numbers one by one, teacher can also mention random numbers with songs and still ask students to demonstrate them.

- Figure 3 shows two of five finger's positions for demonstrating number.

Example: One two, three four, five four, four five

Three two, three five, five two, two one

Un, deux, trois, cinq et quatre, quatre et cinq 
Trois puis deux, Trois puis cinq, Cinq puis deux, deux puis un

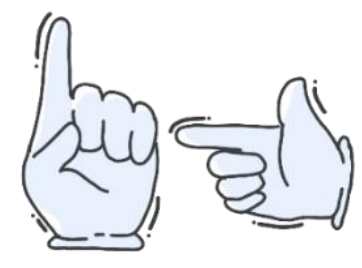

Fig. 3. Finger's number.

4) Title: Subject Whistle

Type: creativity game

Content: nom du cours (lesson's name)

Learning objectives: mention the names of lessons in French

Activity Objectives: train concentration and dexterity, deliver noms du cours material

Implementation:

- Students play classically and teacher prepares four signs in front of the class that represent the four subjects studied by students, for example: Mathematics, English, French, and Indonesian.

- With a whistle, teacher provides instructions for each subject. The whistle blown once represents Mathematics; $2 \mathrm{x}$ English, 3x French and 4x Indonesian. Students must memorize the frequency of whistles blown by the teacher. Every time the whistle is blown, students must run towards the appropriate subject mark.

\subsubsection{Expert's Suggestion}

The draft product that has been compiled is then reviewed by experts, in this case the French language lecturer to know the advantages and disadvantages. The following are the results of the expert validation test:

a. The activities are not monotonous and look fun.

b. Products have varied and include fun elements

c. The initial classification arrangement is less systematic, it would be better to categorize the activities according to the theme and content

d. The steps in the implementation of the game can be more detailed so that so that other people more easily understand and practice it.

e. There is no clear time allocation. It must be remembering that apperception does not take much time so that it will disrupt the time for the main material.

f. Add learning objectives to make it clearer whether the activities carried out for apperception support the learning objectives to be achieved.

\subsubsection{Trial in Class}

The third part discusses the trials of apperception activities in class. The trials were conducted both in high school and university, in this case at the French Language Program of UNNES in the second and third week of September, the following results are known: 
a. Students look enthusiastic for accepting and doing apperception activities while opening the lesson. But they have not been able to control their emotions and enthusiasm so that it seems rather rowdy.

b. There are obstacles faced by the other teacher using the product for understanding commands and rules of the game

c. Students are more controlled in participating in apperception activities.

d. The rules of the game have been made more systematic and clarified so that other teachers can use them.

\section{Conclusion}

The study was conducted with several steps to develop the final product in the form of activite ludique for apperception activities for French beginner learners. These activities comprehend fun story, brain gym, ice breaking, music, creativity games, language games and culture games. According to the result of its application in class, it is hoped that the problem of learning French can be solved. In addition, the product in this study can be a refresher of knowledge for French language teachers in providing apperception activities.

\section{References}

[1] M. Maksum, Menjadi guru idola. Klaten: Cable Book, 2014.

[2] J.-P. Cuq, "Dictionnaire de didactique du français," Paris CLE Int., pp. 214-216, 2003.

[3] S. Handayani, "Les activités de l'apperception cultivée en classe de français," in Actes du Séminaire International, 2014, pp. 140-146.

[4] H. Silva, "La créativité associée au jeu en classe de français langue étrangère," Synerg. Eur., vol. 4, pp. 105-117, 2009.

[5] S. Handayani and D. Astuti, "Introduire l'activité Brise-glace aux professeurs du lycée à Semarang," in Actes du Séminaire International, 2015, pp. 313-320.

[6] L. Harkou, "Pour l'utilisation de l'activité ludique en Algérie dans la classe de FLE," Synerg. Algérie, no. 22, pp. 59-71, 2015.

[7] A. Wijaya, "Penerapan Variasi Kegiatan Apersepsi dan Pembelajaran Interactive Learning untuk Meningkatkan Aktifitas Pembelajaran dan Kemampuan Pronunciation Mahasiswa dalam Mata Kuliah Pronunciation Practice," Didakt. J. Pendidik. dan Ilmu Pengetah., vol. 15, no. 3, 2016.

[8] N. Syaodih Sukmadinata, "Metode Penelitian Pendidikan," Bandung: Rosda, 2007. 